Prepared in cooperation with the Indiana Department of Transportation

\title{
Flood-Inundation Maps for the Iroquois River at Rensselaer, Indiana
}

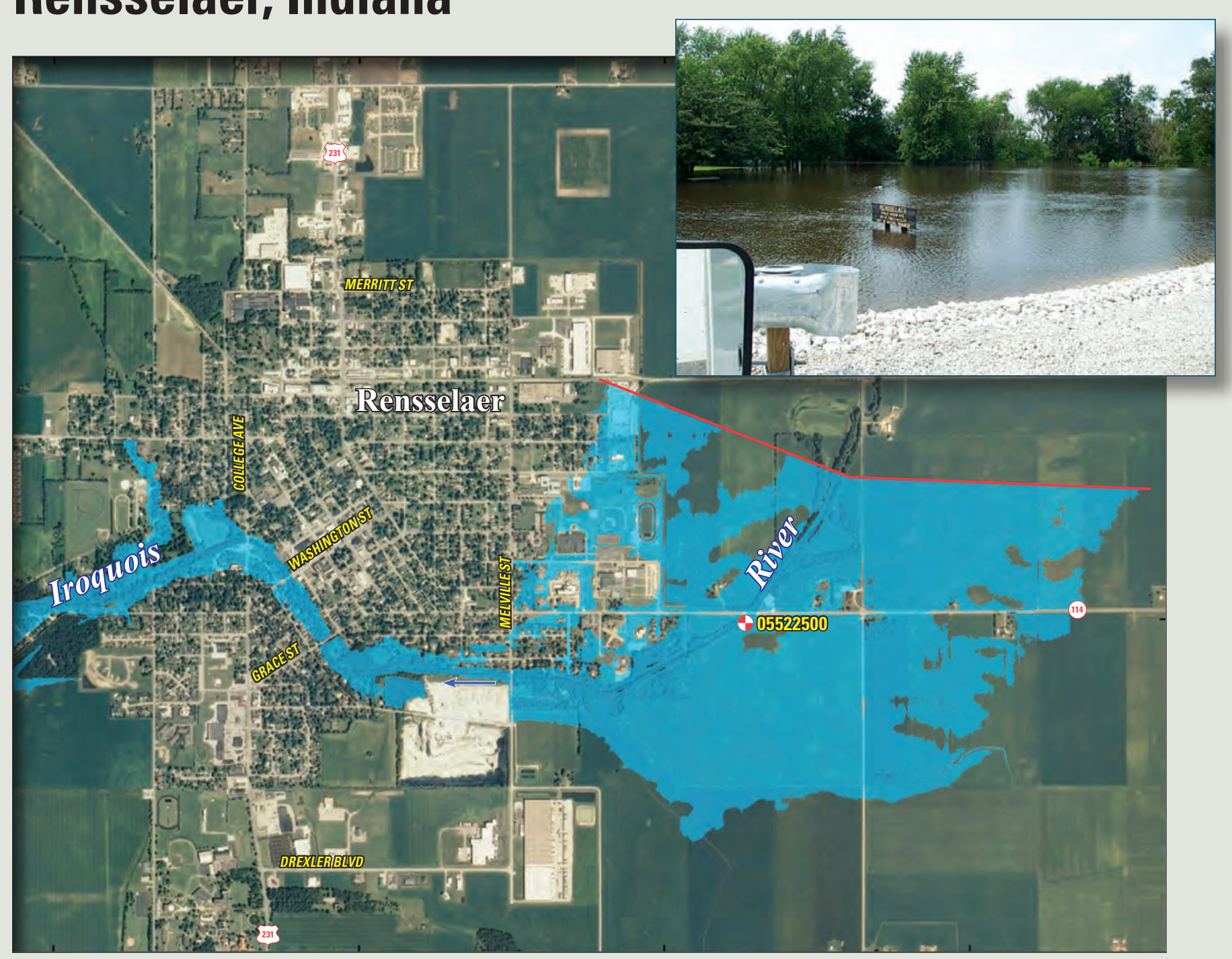

Pamphlet to accompany

Scientific Investigations Map 3246

U.S. Department of the Interior

U.S. Geological Survey 



\section{Flood-Inundation Maps for the Iroquois River at Rensselaer, Indiana}

By Kathleen K. Fowler and Aubrey R. Bunch

Prepared in cooperation with the Indiana Department of Transportation

Pamphlet to accompany

Scientific Investigations Map 3246 


\title{
U.S. Department of the Interior \\ KEN SALAZAR, Secretary
}

\section{U.S. Geological Survey \\ Suzette M. Kimball, Acting Director}

\author{
U.S. Geological Survey, Reston, Virginia: 2013
}

For more information on the USGS - the Federal source for science about the Earth, its natural and living resources, natural hazards, and the environment, visit http://www.usgs.gov or call 1-888-ASK-USGS.

For an overview of USGS information products, including maps, imagery, and publications, visit http://www.usgs.gov/pubprod

To order this and other USGS information products, visit http://store.usgs.gov

Any use of trade, firm, or product names is for descriptive purposes only and does not imply endorsement by the U.S. Government.

Although this information product, for the most part, is in the public domain, it also may contain copyrighted materials as noted in the text. Permission to reproduce copyrighted items must be secured from the copyright owner.

Suggested citation:

Fowler, K.K., and Bunch, A.R., 2013, Flood-inundation maps for the Iroquois River at Rensselaer, Indiana: U.S. Geological Survey Scientific Investigations Map 3246, 9 map sheets, 8-p pamphlet. 


\section{Acknowledgments}

The authors wish to thank the agencies that have cooperated in the funding for the operation and maintenance of the gage used for this study, especially the Indiana Department of Natural Resources. Special thanks are given to the Indiana Department of Transportation for their cooperation in this study and to the National Weather Service for their continued support to the USGS flood-inundation mapping program. In addition, the authors would like to acknowledge the particularly strong and constructive peer review provided by Chris Hoard from the USGS Michigan Water Science Center. 


\section{Contents}

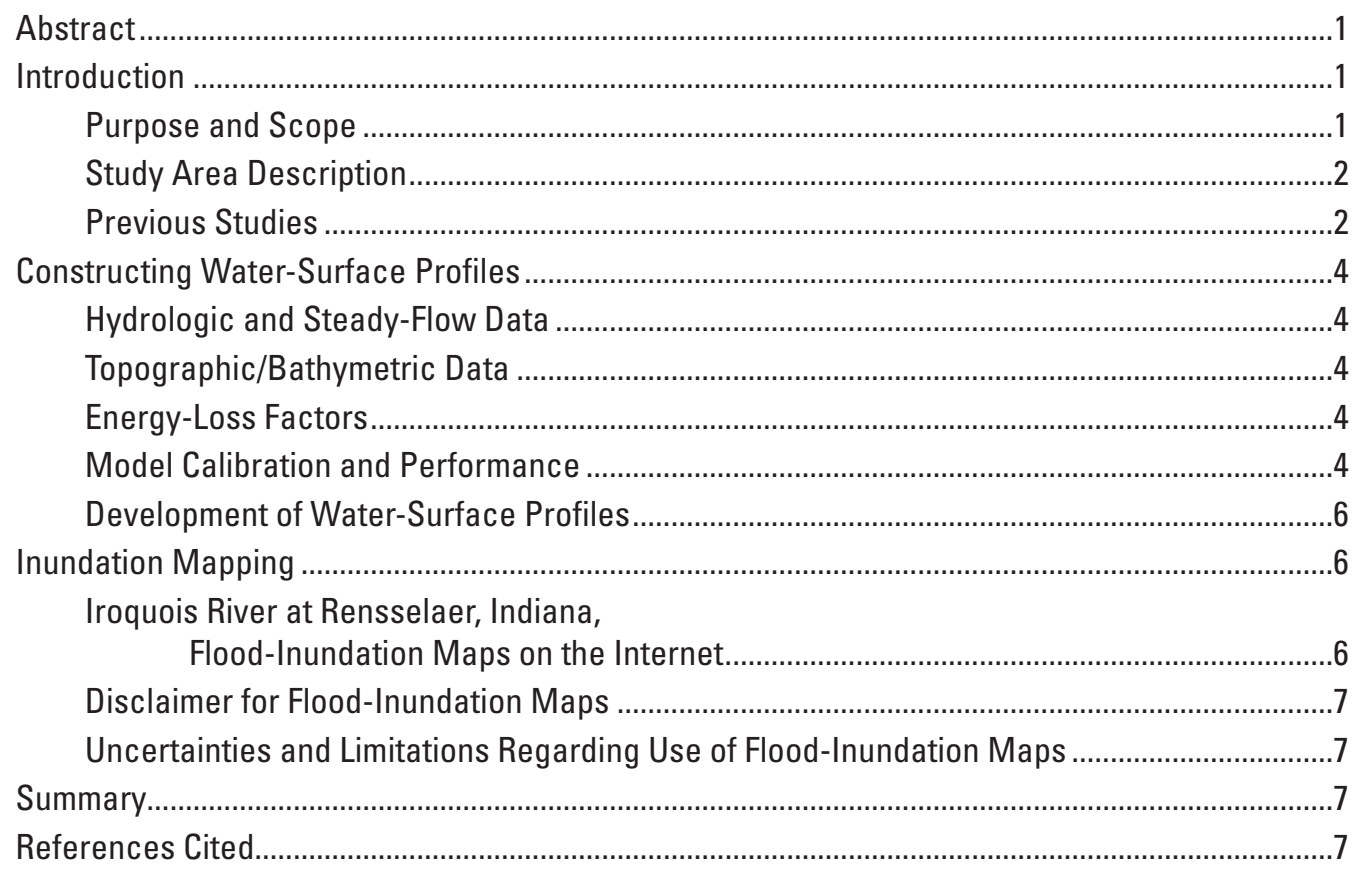

\section{Figures}

1. Map of location of study reach for the Iroquois River and location of USGS streamgage 05522500 (National Weather Service forecast site RZLI3)..................3

\section{Tables}

1. USGS streamgage information for the Iroquois River at Rensselaer, Indiana. .................2

2. 1.0 percent annual exceedance probability peak-discharge estimate and drainage area for USGS streamgage 05522500, Rensselaer, Indiana........................2

3. Comparison of water-surface elevations at USGS streamgage 05522500 , Iroquois River at Rensselaer, Indiana, with water-surface elevations output from the hydraulic model

4. Comparison of hydraulic-model output and surveyed high-water-mark elevations from the flood of July 2003 for the Iroquois River at Rensselaer, Indiana.

5. Stages and water-surface elevations, in feet, with corresponding discharge estimates at USGS streamgage 05522500, Iroquois River at Rensselaer, Indiana, for simulated water-surface profiles. 


\section{Map Sheets}

Separate documents available on Web only

1-9. Flood-inundation maps for the Iroquois River at Rensselaer, Indiana, at the

U.S. Geological Survey streamgage 05522500 for a corresponding stage of-

1. $\quad 11.00$ feet and an elevation of 653.00 feet

2. 12.00 feet and an elevation of 654.00 feet

3. 13.00 feet and an elevation of 655.00 feet

4. $\quad 14.00$ feet and an elevation of 656.00 feet

5. $\quad 15.00$ feet and an elevation of 657.00 feet

6. $\quad 16.00$ feet and an elevation of 658.00 feet

7. 17.00 feet and an elevation of 659.00 feet

8. $\quad 18.00$ feet and an elevation of 660.00 feet

9. $\quad 19.00$ feet and an elevation of 661.00 feet

\section{Conversion Factors}

\begin{tabular}{|c|c|c|}
\hline Multiply & By & To obtain \\
\hline \multicolumn{3}{|c|}{ Length } \\
\hline foot $(\mathrm{ft})$ & 0.3048 & meter $(\mathrm{m})$ \\
\hline mile (mi) & 1.609 & kilometer $(\mathrm{km})$ \\
\hline \multicolumn{3}{|c|}{ Area } \\
\hline square mile $\left(\mathrm{mi}^{2}\right)$ & 2.590 & square kilometer $\left(\mathrm{km}^{2}\right)$ \\
\hline \multicolumn{3}{|c|}{ Flow rate } \\
\hline cubic foot per second $\left(\mathrm{ft}^{3} / \mathrm{s}\right)$ & 0.02832 & cubic meter per second $\left(\mathrm{m}^{3} / \mathrm{s}\right)$ \\
\hline \multicolumn{3}{|c|}{ Hydraulic gradient } \\
\hline foot per mile $(\mathrm{ft} / \mathrm{mi})$ & 0.1894 & meter per kilometer $(\mathrm{m} / \mathrm{km})$ \\
\hline
\end{tabular}

Vertical coordinate information is referenced to either (1) stage, the height above an arbitrary datum established at a streamgage, or (2) elevation, the height above North American Vertical Datum of 1988 (NAVD 88).

Horizontal coordinate information is referenced to the North American Datum of 1983 (NAD 83). 


\title{
Flood-Inundation Maps for the Iroquois River at Rensselaer, Indiana
}

\author{
By Kathleen K. Fowler and Aubrey R. Bunch
}

\section{Abstract}

Digital flood-inundation maps for a 4.0-mile reach of the Iroquois River at Rensselaer, Indiana (Ind.), were created by the U.S. Geological Survey (USGS) in cooperation with the Indiana Department of Transportation. The inundation maps, which can be accessed through the USGS Flood Inundation Mapping Science Web site at http://water.usgs.gov/osw/flood inundation/, depict estimates of the areal extent and depth of flooding corresponding to selected water levels (stages) at USGS streamgage 05522500, Iroquois River at Rensselaer, Ind. Current conditions for estimating near-real-time areas of inundation using USGS streamgage information may be obtained on the Internet at (http://waterdata.usgs.gov/in/nwis/ $u v$ ? site_no=05522500). In addition, the National Weather Service (NWS) forecasts flood hydrographs at the Rensselaer streamgage. That forecasted peak-stage information, also available on the Internet (http:/water.weather.gov/ahps/), may be used in conjunction with the maps developed in this study to show predicted areas of flood inundation.

For this study, flood profiles were computed for the Iroquois River reach by means of a one-dimensional stepbackwater model developed by the U.S. Army Corps of Engineers. The hydraulic model was calibrated by using the most current (June 27, 2012) stage-discharge relations at USGS streamgage 05522500, Iroquois River at Rensselaer, Ind., and high-water marks from the flood of July 2003. The calibrated hydraulic model was then used to determine nine water-surface profiles for flood stages at 1-foot intervals referenced to the streamgage datum and ranging from bankfull to the highest stage of the current stage-discharge rating curve. The simulated water-surface profiles were then combined with a Geographic Information System digital elevation model (derived from Light Detection and Ranging (LiDAR) data) in order to delineate the area flooded at each water level.

The availability of these maps, along with Internet information regarding current stage from the USGS streamgage at Rensselaer, Ind., and forecasted stream stages from the NWS, provides emergency management personnel and residents with information that is critical for flood response activities such as evacuations and road closures, as well as for post-flood recovery efforts.

\section{Introduction}

The city of Rensselaer, Indiana (Ind.) is a small urban community with an estimated population of 5,859 (U.S. Census Bureau, 2010). Rensselaer has experienced severe flooding numerous times, most recently in 2009. Areas most affected by the flooding are along the Iroquois River, which flows through the town. Flood plains within Rensselaer are moderately developed and contain a mix of residential, commercial, and agricultural areas.

Prior to this study, Rensselaer officials relied on several information sources to make decisions on how to best alert the public and mitigate flood damages. One source of information is the Federal Emergency Management Agency (FEMA) Flood Insurance Study (FIS) for Jasper County dated 2007 (Federal Emergency Management Agency, 2007). A second source is USGS streamgage 05522500, Iroquois River at Rensselaer, Ind., from which current and historical water levels (stage) can be obtained. A third source is the National Weather Service's forecast of peak stage at USGS streamgage 05522500 , Iroquois River at Rensselaer, Ind., through their Advanced Hydrologic Prediction Service (AHPS) Web site. Although USGS stream stage and NWS flood forecast information is particularly useful for residents in the immediate vicinity of a streamgage, it is of limited use to residents farther upstream or downstream because the water-surface elevation is not constant along the entire stream channel. Also, FEMA and State emergency management mitigation teams and property owners typically lack information related to water elevation at locations other than near USGS streamgages or NWS floodforecast points.

\section{Purpose and Scope}

The purpose of this report is to describe the development of a series of estimated flood-inundation maps for the Iroquois River at Rensselaer, Ind. The maps and other flood information are available on the USGS Flood Inundation Mapping Science Web site. Internet users can select estimated inundation maps that correspond to (1) flood stages at USGS streamgage 05522500 and (2) the NWS forecasted peak stage. 
The scope of the study was limited to the Iroquois River reach extending 0.6 mi upstream of USGS streamgage 05522500 at the State Road 114 bridge and $3.4 \mathrm{mi}$ downstream of the streamgage (fig. 1). Tasks specific to construction of the maps were (1) compilation of flow data from streamgage 05522500 , (2) collection of topographic data and geometric data (for structures/bridges) throughout the study reach, (3) estimation of energy-loss factors (roughness coefficients) in the stream channel and flood plain, (4) computation of water-surface profiles by use of the U.S. Army Corps of Engineers' HEC-RAS computer program (U.S. Army Corps of Engineers, 2010), (5) production of estimated flood-inundation maps at various stream stages by use of the U.S. Army Corps of Engineers' HEC-GeoRas computer program (U.S. Army Corps of Engineers, 2009) and a Geographic Information System (GIS), and (6) development of a Web interface that links to USGS real-time streamgage information and NWS forecasted peak stage to facilitate the display of user-selected flood-inundation maps on the Internet.

Methods used are generally cited from previously published reports. If techniques varied significantly from previously documented methods due to local hydrologic conditions or available data, they are described in detail in this report. Nine maps were produced for water levels referenced to the water-surface elevation (stage) at USGS streamgage 05522500, Iroquois River at Rensselaer, Ind., and ranging from approximately bankfull to the maximum observed water level at the streamgage.

\section{Study Area Description}

The Iroquois River near the city of Rensselaer is in northwest Indiana in the Iroquois Till Plain physiographic section of the Central Till Plain Region (Gray, 2000). The drainage area is $202 \mathrm{mi}^{2}$ at the upstream end of the study reach, $203 \mathrm{mi}^{2}$ at USGS streamgage 05522500 , Iroquois River at Rensselaer, and $214 \mathrm{mi}^{2}$, at the downstream extent of the study reach. The headwaters originate in Jasper County, and the stream flows generally southward before entering the city limits. In Rensselaer the river flows from east to west. There are no significant tributaries to the Iroquois River as it flows through Rensselaer. The basin terrain is generally flat, with a few low rises. The area is poorly drained even though it has been extensively ditched to allow farming. The study reach is approximately $4.0 \mathrm{mi}$ long and has an average top-of-bank channel width of about $90 \mathrm{ft}$ and an average channel slope of $0.0003(1.7 \mathrm{ft} / \mathrm{mi})$. About 54 percent of the land contiguous to the study reach is classified as urban or developed, 44 percent is either agricultural or natural areas, and 2 percent is parks and recreation areas (City of Rensselaer, 2007). The basin is still under development, as evidenced by a population increase of 10.7 percent (from 5,294 to 5,859) between 2000 and 2010 (U.S. Census Bureau, 2010). The main channel within the study reach has five major road crossings that lie within the channel or the adjacent flood plain.

\section{Previous Studies}

The current FIS for Jasper County (Federal Emergency Management Agency, 2007) was completed by Lawson-Fisher Associates in 2004 and supersedes an earlier study completed by the U.S. Department of Agriculture in 1986. The 1986 study used approximate methods to determine flood hazards for 14 of the county's streams. The Iroquois River was one of the streams studied by approximate methods, and the resultant Special Flood Hazards Area map was used for comparison purposes. The 2004 FIS did not update the Iroquois River analysis, but it is included in the text along with information about the City of Rensselaer. An estimate of the peak discharge for the 1.0 percent annual exceedance probability flood at the Rensselaer gage on the Iroquois River was obtained from USGS Streamstats for Indiana (U.S. Geological Survey, 2012) and is listed in table 2.

Table 1. USGS streamgage information for the Iroquois River at Rensselaer, Indiana.

[mi ${ }^{2}$, square miles; NAD 83, North American Datum of 1983; NAVD 88, North American Vertical Datum of 1988; ft, feet]

\begin{tabular}{cccccccc}
\hline Streamgage name & $\begin{array}{c}\text { Streamgage } \\
\text { number }\end{array}$ & $\begin{array}{c}\text { Drainage } \\
\text { area } \\
\left(\mathbf{m i}^{2}\right)\end{array}$ & $\begin{array}{c}\text { Latitude } \\
\text { (NAD 83) }\end{array}$ & $\begin{array}{c}\text { Longitude } \\
\text { (NAD 83) }\end{array}$ & $\begin{array}{c}\text { Period of } \\
\text { record }\end{array}$ & $\begin{array}{c}\text { Datum } \\
\text { of gage } \\
\text { (NAVD 88) }\end{array}$ & $\begin{array}{c}\text { Maximum recorded } \\
\text { flood elevation } \\
\text { (NAVD 88) and date }\end{array}$ \\
\hline $\begin{array}{c}\text { Iroquois River at } \\
\text { Rensselaer, Indiana }\end{array}$ & 05522500 & 203 & $40^{\circ} 56^{\prime} 00^{\prime \prime}$ & $87^{\circ} 07^{\prime} 44^{\prime \prime}$ & $\begin{array}{c}\text { October } 1948 \\
\text { to present }\end{array}$ & $\begin{array}{c}642.00 \mathrm{ft} \\
658.59 \mathrm{ft} \text { on July 10, } \\
2003(\text { corresponds to } \\
\text { a stage of } 16.59 \mathrm{ft})\end{array}$ \\
\hline
\end{tabular}

Table 2. 1.0 percent annual exceedance probability peak-discharge estimate and drainage area for USGS streamgage 05522500, Rensselaer, Indiana.

$\left[\mathrm{mi}^{2}\right.$, square miles; $\mathrm{ft}^{3} / \mathrm{s}$, cubic feet per second]

\begin{tabular}{lccc}
\hline \multicolumn{1}{c}{ Location } & $\begin{array}{c}\text { Discharge estimate } \\
\left(\mathbf{f t}^{3} \mathbf{s}\right)\end{array}$ & Stage estimate & Drainage area (mi $\left.{ }^{2}\right)$ \\
\hline Iroquois River at State Road 114, USGS streamgage 05522500 & 2450 & 15.41 & 203 \\
\hline
\end{tabular}




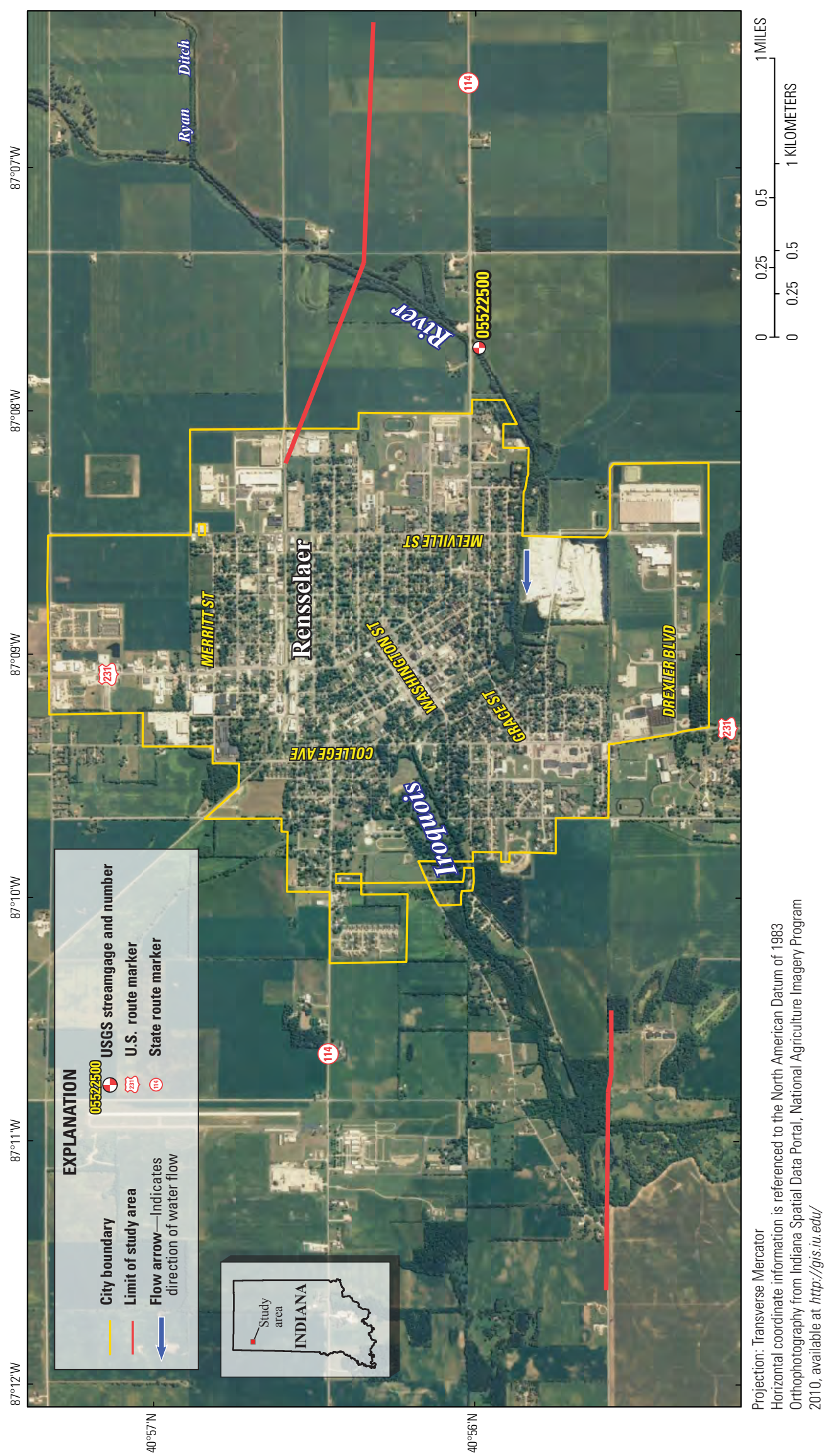

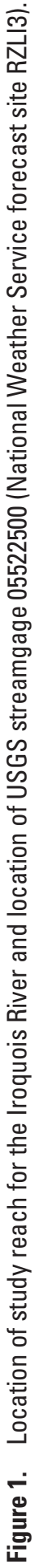




\section{Constructing Water-Surface Profiles}

The water-surface profiles used to produce the nine flood-inundation maps in this study were simulated by using HEC-RAS, version 4.1.0 (U.S. Army Corps of Engineers, 2010). HEC-RAS is a one-dimensional step-backwater model for simulation of water-surface profiles with gradually varied, steady-state (or unsteady-state) flow computation options. The HEC-RAS analysis for this study was done using the steadystate flow computation option.

\section{Hydrologic and Steady-Flow Data}

The study area hydrologic network consists of one streamgage (fig. 1; table 1), which has been in operation since 1949. This gage has a continuous record of measured water level (stage) and computed streamflow. Water-surface elevations corresponding to the stages are referenced to North American Vertical Datum of 1988 (NAVD 88) in this report. The USGS gage is equipped with satellite radio transmitters that allow data to be transmitted routinely on the Internet within an hour of collection. Flow data for this gage can be accessed at http://waterdata.usgs.gov/in/nwis/uv/?site $n o=05522500 \&$ PARAmeter_cd $=00065,00060,00010$.

The steady-flow data necessary for the hydraulic model consisted of flow regime, boundary conditions (normal depth), and peak-discharge information. The steady-flow data for the model were obtained from field measurements of streamflow at USGS streamgage 05522500, Iroquois River at Rensselaer, Ind. All computations used discharge values with known stages from actual streamflow measurements or the stagedischarge relations at the gage.

\section{Topographic/Bathymetric Data}

Channel cross sections were developed from USGS field surveys that were conducted in December 2011. These cross sections provide detailed channel-elevation data below the water surface and were collected by using hydroacoustic instrumentation to measure depth in conjunction with Differential Global Positioning System (DGPS) instrumentation to determine horizontal position. Light Detection and Ranging (LiDAR) data were used to obtain digital elevation data for the portions of the cross sections that were above the water surface at the time of the surveys. The LiDAR data for the Iroquois River at Rensselaer were collected and post-processed by Aero-Metric, Inc., Sheboygan, Wisconsin (Wis.), in 2010. The LiDAR data have horizontal accuracy of $1.02 \mathrm{ft}$ with horizontal resolution of $3.9 \mathrm{ft}$ and vertical accuracy of $0.37 \mathrm{ft}$ at a 95-percent confidence level. Although a finer resolution of the digital elevation model (DEM) was possible given the accuracy of the LiDAR data, the final DEM had a grid-cell size of $10 \mathrm{ft}$ by $10 \mathrm{ft}$ in order to decrease the GIS processing time.
Various manmade drainage structures (bridges, culverts, roadway embankments, levees, and dams) in and along the Iroquois River affect or have the potential to affect water-surface elevations during floods along the stream. To properly account for these features in the model, structural dimensions for five bridges were measured and surveyed in the field concurrently with the stream channel surveys. A detailed description of the methods used to acquire and process the topographic and bathymetric data can be found in Bales and others (2007).

\section{Energy-Loss Factors}

Field observations and high-resolution aerial photographs obtained from the Indiana Spatial Data Portal, National Agricultural Imagery Program 2010 (http://gis.iu.edu/) were used to select initial channel and flood-plain friction coefficients. These friction coefficients, commonly called Manning's roughness coefficients or Manning's n values, account for energy (friction) loss in the model (Arcement and Schneider, 1989). Preliminary estimates of Manning's $n$ values ranged from 0.030 to 0.035 for the main channel and 0.06 to 0.13 for the overbank areas modeled in this analysis. For the area near the State Road 114 Bridge, the Manning's n values were adjusted by roughness factors that increase or decrease the assigned coefficients at specified areas and or flows. The application of these factors resulted in main channel Manning's n values ranging from 0.014 to 0.036 and overbank Manning's n values from 0.05 to 0.14 .

\section{Model Calibration and Performance}

The hydraulic model was calibrated to the most current stage-discharge relation (USGS rating no. 38, June 27, 2012) at USGS streamgage 05522500 , Iroquois River at Rensselaer, Ind., and high-water marks from the flood of 2003 . The estimated peak discharge for the 2003 flood was $2,850 \mathrm{ft}^{3} / \mathrm{s}$ at an estimated stage of about $16.59 \mathrm{ft}$ at the gage. Model calibration was accomplished by adjusting Manning's $n$ values and, in some cases, changing the channel cross section or slope until the results of the hydraulic computations closely agreed with the known flood discharge and stage values. Differences between measured and simulated water levels at USGS gaging station 05522500 were equal to or less than $0.38 \mathrm{ft}$ for seven of the nine profiles and within $0.49 \mathrm{ft}$ for the remaining two profiles (table 3). Differences between measured and simulated water levels for models calibrated to high-water marks from the flood of 2003 in the study reach were less than $0.53 \mathrm{ft}$ (table 4). An additional comparison was made to the Indiana Department of Natural Resources' graph of flood profiles for the Iroquois River (Basin 4) (Joseph Mallory, written commun., 2012). The results demonstrate that the model is capable of simulating accurate water levels over a wide range of flows in the basin. Details on techniques used in model development and calibration can be found in Bales and others (2007). 
Table 3. Comparison of water-surface elevations at USGS streamgage 05522500, Iroquois River at Rensselaer, Indiana, with water-surface elevations output from the hydraulic model.

[ft, feet; NAVD 88, North American Vertical Datum of 1988]

\begin{tabular}{cccc}
\hline $\begin{array}{c}\text { Stage } \\
\text { (ft) }\end{array}$ & $\begin{array}{c}\text { Estimated } \\
\text { water-surface } \\
\text { elevation from } \\
\text { stage-discharge } \\
\text { rating } \\
\text { (ft, NAVD 88) }\end{array}$ & $\begin{array}{c}\text { Modeled } \\
\text { water-surface } \\
\text { elevation } \\
\text { (ft, NAVD 88) }\end{array}$ & $\begin{array}{c}\text { Elevation } \\
\text { difference } \\
\text { (ft) }\end{array}$ \\
\hline 11.00 & 653.00 & 653.38 & -0.38 \\
12.00 & 654.00 & 654.45 & -0.45 \\
13.00 & 655.00 & 655.32 & -0.32 \\
14.00 & 656.00 & 656.05 & -0.05 \\
15.00 & 657.00 & 657.09 & -0.09 \\
16.00 & 658.00 & 658.01 & -0.01 \\
17.00 & 659.00 & 659.21 & -0.21 \\
18.00 & 660.00 & 659.86 & 0.14 \\
19.00 & 661.00 & 660.51 & 0.49 \\
\hline
\end{tabular}

Table 4. Comparison of hydraulic-model output and surveyed high-water-mark elevations from the flood of July 2003 for the Iroquois River at Rensselaer, Indiana.

[ ft, feet; NAVD 88, North American Vertical Datum of 1988]

\begin{tabular}{|c|c|c|c|c|}
\hline Location & $\begin{array}{c}\text { High-water } \\
\text { mark field } \\
\text { identification } \\
\text { number' }\end{array}$ & $\begin{array}{c}\text { High-water } \\
\text { mark } \\
\text { elevation } \\
\text { (ft, NAVD 88) }\end{array}$ & $\begin{array}{c}\text { Model } \\
\text { water-surface } \\
\text { elevation } \\
\text { (ft, NAVD 88) }\end{array}$ & $\begin{array}{c}\text { Elevation } \\
\text { difference } \\
\text { (ft) }\end{array}$ \\
\hline $\begin{array}{l}\text { Upstream side of State Road } \\
114 \text { bridge }\end{array}$ & 7 & 658.74 & 659.02 & -0.28 \\
\hline $\begin{array}{l}\text { Downstream side of State } \\
\text { Road } 114 \text { bridge }\end{array}$ & 8 & 658.67 & 658.93 & -0.26 \\
\hline $\begin{array}{l}\text { Upstream side of Melville } \\
\text { Street bridge }\end{array}$ & 9 & 657.79 & 657.47 & 0.32 \\
\hline $\begin{array}{l}\text { Downstream side of Melville } \\
\text { Street bridge }\end{array}$ & 10 & 657.83 & 657.31 & 0.52 \\
\hline $\begin{array}{l}\text { Upstream side of Grace } \\
\text { Street bridge }\end{array}$ & 11 & 653.81 & 654.59 & -0.78 \\
\hline $\begin{array}{l}\text { Downstream side of Grace } \\
\text { Street bridge }\end{array}$ & 12 & 654.09 & 654.48 & -0.39 \\
\hline $\begin{array}{l}\text { Upstream side of Washington } \\
\text { Street bridge }\end{array}$ & 13 & 653.89 & 653.70 & 0.19 \\
\hline $\begin{array}{l}\text { Downstream side of Wash- } \\
\text { ington Street bridge }\end{array}$ & 14 & 653.82 & 653.61 & 0.21 \\
\hline $\begin{array}{l}\text { Upstream side of College } \\
\text { Avenue bridge }\end{array}$ & 15 & 653.4 & 653.20 & 0.20 \\
\hline $\begin{array}{l}\text { Downstream side of College } \\
\text { Avenue bridge }\end{array}$ & 16 & 653.41 & 653.06 & 0.35 \\
\hline River Mile 82.9 & 18 & 653.08 & 652.57 & 0.51 \\
\hline
\end{tabular}




\section{Development of Water-Surface Profiles}

Profiles were developed for a total of nine stages at 1 -ft intervals between $11 \mathrm{ft}$ and $19 \mathrm{ft}$ as referenced to USGS streamgage 05522500, Iroquois River at Rensselaer, Ind. Discharges corresponding to the various stages were obtained from the most current stage-discharge relation (rating no. 38, June 27, 2012) at the Iroquois River gage.

Discharges for all profiles (table 5) were selected with the assumption that within the 4.0-mi study reach there are no significant tributary or groundwater inflows. The discharges were estimated to be uniform and steady throughout the study reach.

\section{Inundation Mapping}

Flood-inundation maps were created for a stream reach near Rensselaer, Ind. The maps were created in a Geographic Information System by combining the water-surface profiles and digital elevation model data. The digital elevation model (DEM) data were derived from Light Detection and Ranging (LiDAR) data that were collected during April 2010, by Aero-Metric, Inc., Sheboygan, Wis. Post-processing of these data was completed by Aero-Metric, Inc., on July 14, 2010. The LiDAR data have horizontal accuracy of $1.02 \mathrm{ft}$ with horizontal resolution of $3.9 \mathrm{ft}$ and vertical accuracy of $0.37 \mathrm{ft}$ at a 95-percent confidence level. Estimated flood-inundation boundaries for each simulated profile were developed with HEC-GeoRAS software (U.S. Army Corps of Engineers, 2009). HEC-GeoRAS is a set of procedures, tools, and utilities for processing geospatial data in ArcGIS using a graphical user interface. The interface allows the preparation of geometric data for import into HEC-RAS and processes simulation results exported from HEC-RAS (U.S. Army Corps of Engineers, 2010). USGS personnel then modified the HECGeoRAS results to ensure a hydraulically reasonable transition of the boundary between modeled cross sections relative to the contour data for the land surface (Whitehead and Ostheimer, 2009). The resulting maps show estimated flood-inundated areas overlaid on high-resolution, georeferenced aerial photographs of the study area for each of the water-surface profiles that were generated by the hydraulic model.

\section{Iroquois River at Rensselaer, Indiana, Flood-Inundation Maps on the Internet}

The flood-inundation maps and current study documentation are available online at the U.S. Geological Survey Publications Warehouse (http://pubs.usgs.gov/sim/2012/3246). Also, a Flood Inundation Mapping Science Web site has been established to provide a portal for USGS flood-inundation study information to the public at http://water.usgs.gov/osw/ flood_inundation/. That Web portal has a link (http://wim. usgs.gov/FIMI/FloodInundationMapper.html) to an interactive mapping application where flood maps can be downloaded in several commonly used electronic file formats. At the mapping application site, each stream reach displayed contains further links to NWISWeb graphs of the current stage and streamflow at USGS streamgage 05522500 , to which the inundation maps are referenced. A link also is provided to the NWS Advanced Hydrologic Prediction Service (AHPS) site (http:/ water.weather.gov/ahps/), where the NWS forecasts river stage at Rensselaer during times of flooding. In addition to maps showing areas of inundation, downloadable GIS raster files and keyhole markup language (KML) map files are available. The estimated flood-inundation maps are displayed in sufficient detail to note the extent of flooding with respect to individual structures so that preparations for flooding and decisions for emergency response can be performed efficiently. Roadways and bridges were closely reviewed and are shown as shaded (inundated and likely impassable) or not shaded (dry and passable) to facilitate emergency planning and use. However, buildings which are shaded do not reflect inundation but denote that bare earth surfaces in the vicinity of the buildings are inundated. When the water depth (as indicated in the Web mapping application by holding the cursor over an inundated area) in the vicinity of the building of interest exceeds that building's height, the structure can be considered fully submerged.

Table 5. Stages and water-surface elevations, in feet, with corresponding discharge estimates at USGS streamgage 05522500, Iroquois River at Rensselaer, Indiana, for simulated water-surface profiles.

[mi², square miles; $\mathrm{ft}^{3} / \mathrm{s}$, cubic feet per second; NAVD 88, North American Vertical Datum of 1988]

\begin{tabular}{|c|c|c|c|c|c|c|c|c|c|c|}
\hline \multirow[b]{2}{*}{ Location } & \multirow[b]{2}{*}{$\begin{array}{l}\text { Drainage } \\
\text { area }\left(\mathrm{mi}^{2}\right)\end{array}$} & \multicolumn{9}{|c|}{ Stage, in feet above gage datum at the Iroquois River (reference datum 642.00 NAVD 88) } \\
\hline & & $\begin{array}{c}11.0 \\
(653.00)\end{array}$ & $\begin{array}{c}12.0 \\
(654.00)\end{array}$ & $\begin{array}{c}13.0 \\
(655.00)\end{array}$ & $\begin{array}{c}14.0 \\
(656.00)\end{array}$ & $\begin{array}{c}15.0 \\
(657.00)\end{array}$ & $\begin{array}{c}16.0 \\
(658.00)\end{array}$ & $\begin{array}{c}17.0 \\
(659.00)\end{array}$ & $\begin{array}{c}18.0 \\
(660.00)\end{array}$ & $\begin{array}{c}19.0 \\
(661.00)\end{array}$ \\
\hline & & \multicolumn{9}{|c|}{ Discharge $\left(\mathrm{ft}^{3} / \mathrm{s}\right)$} \\
\hline $\begin{array}{l}\text { Streamgage number } \\
05522500\end{array}$ & 203.00 & 2,000 & 1,450 & 1,720 & 2,010 & 2,320 & 2,650 & 3,000 & 3,360 & 3,750 \\
\hline
\end{tabular}




\section{Disclaimer for Flood-Inundation Maps}

Inundated areas shown should not be used for navigation, regulatory, permitting, or other legal purposes. The USGS provides these maps "as-is" for a quick reference, emergency planning tool but assumes no legal liability or responsibility resulting from the use of this information.

\section{Uncertainties and Limitations Regarding Use of Flood-Inundation Maps}

Although the flood-inundation maps represent the boundaries of inundated areas with a distinct line, some uncertainty is associated with these maps. The flood boundaries shown were estimated based on water stages (water-surface elevations) and streamflows at USGS streamgage at 05522500, Iroquois River at Rensselaer, Ind. Water-surface elevations along the stream reaches were estimated by steady-state hydraulic modeling, assuming unobstructed flow, and using discharges and hydrologic conditions anticipated at the USGS streamgage. The hydraulic model reflects the land-cover characteristics and any bridge, dam, levee, or other hydraulic structures existing as of December 2011. Unique meteorological factors (timing and distribution of precipitation) may cause actual discharges along the modeled reach to vary from those assumed during a flood and lead to deviations in the water-surface elevations and inundation boundaries shown. Additional areas may be flooded due to unanticipated conditions such as changes in the streambed elevation or roughness, backwater into tributaries along a main stem river, or backwater from localized debris or ice jams. The accuracy of the floodwater extent portrayed on these maps will vary with the accuracy of the digital elevation model used to simulate the land surface. Additional uncertainties and limitations pertinent to this study are described elsewhere in this report.

If this series of flood-inundation maps will be used in conjunction with National Weather Service (NWS) river forecasts, the user should be aware of additional uncertainties that may be inherent or factored into NWS forecast procedures. The NWS uses forecast models to estimate the quantity and timing of water flowing through selected stream reaches in the United States. These forecast models (1) estimate the amount of runoff generated by precipitation and snowmelt, (2) simulate the movement of floodwater as it proceeds downstream, and (3) predict the flow and stage (and watersurface elevation) for the stream at a given location (AHPS forecast point) throughout the forecast period (every 6 hours and 3 to 5 days out in many locations). For more information on AHPS forecasts, please see http://water.weather.gov/ahps/ pcpn_and_river_forecasting.pdf.

\section{Summary}

A series of estimated flood-inundation maps was developed in cooperation with the Indiana Department of Transportation for the Iroquois River at Rensselaer, Ind. The maps were developed by using the U.S. Army Corps of Engineers' HEC-RAS and HEC-GeoRAS programs. HEC-RAS is a onedimensional step-backwater model and was used to compute nine water-surface profiles for a 4.0-mi-long reach of the Iroquois River. The HEC-GeoRAS program was used to delineate estimated flood-inundation areas at $1-\mathrm{ft}$ increments of stage as referenced to USGS streamgage 05522500, Iroquois River at Rensselaer, Ind. The modeled stages ranged from $11.0 \mathrm{ft}$, or bankfull, to $19.0 \mathrm{ft}$, the highest stage of the current stage-discharge rating curve.

The inundation maps show estimated (shaded) floodinundation areas overlaid on high-resolution, georeferenced aerial photographs of the study area. The maps were modified, as required, to remove any inundated areas that were detached from the main channel and were erroneously delineated as part of the flood extent. In addition to maps showing areas of inundation, downloadable GIS raster files and KML map files were produced. Interactive use of the maps using the mouse cursor to click within the shaded areas can give users a general indication of depth of water at any point.

These maps, available at a USGS Web portal, in conjunction with the real-time stage data from USGS streamgage 05522500, Iroquois River at Rensselaer, Ind., and National Weather Service flood-stage forecasts, can help to guide the general public in taking individual safety precautions and can provide local officials with a tool to efficiently manage emergency flood operations and flood mitigation efforts.

\section{References Cited}

Aero-Metric, Inc., 2010, Indiana Flood LiDAR (ARRA) Task order, remote-sensing image: Sheboygan, Wis., Aero-Metric, Inc.

Arcement, G.J., and Schneider, V.R., 1989, Guide for selecting Manning's roughness coefficients for natural channels and flood plains: U.S. Geological Survey Water-Supply Paper $2339,38 \mathrm{p}$.

Bales, J.D., Wagner, C.R., Tighe, K.C., and Terziotti, Silvia, 2007, LiDAR-derived flood-inundation maps for realtime flood-mapping applications, Tar River Basin, North Carolina: U.S. Geological Survey Scientific Investigations Report 2007-5032, 42 p.

City of Rensselaer (Indiana), 2007, Comprehensive plan: 62 p., available at $h t t p: / / w w w . c i t y o f r e n s s e l a e r i n . c o m / e g o v /$ docs/1222975993_193542.pdf. 
Federal Emergency Management Agency (FEMA), 2007, Flood Insurance Study for Jasper County, Indiana: Washington D.C., Flood Insurance Study Number 18073CV000A, $21 \mathrm{p}$.

Gray, H.H., 2000, Physiographic divisions of Indiana: Bloomington, Ind., Indiana Geological Survey Special Report 61, $15 \mathrm{p} ., 1 \mathrm{pl}$.

U.S. Army Corps of Engineers, Hydrologic Engineering Center, 2009, HEC-GeoRAS, GIS tools for support of HEC-RAS using ArcGIS, user's manual [variously paged]: Available at http://www.hec.usace.army.mil/software/hecras/hec-georas_downloads.html.

U.S. Army Corps of Engineers, Hydrologic Engineering Center, 2010, HEC-RAS river analysis system, hydraulic reference manual, version 4.1 [variously paged]: Available at $h t t p: / / w w w . h e c . u s a c e . a r m y . m i l / s o f t w a r e / h e c-r a s / h e c r a s-$ download.html.

U.S. Census Bureau, 2010, 2010 Census interactive population search IN- Rensselaer city: Washington, D.C., available at $h t t p: / / 2010 . c e n s u s . g o v / 2010$ census/popmap/ipmtext. $p h p ? f l=1863792$.

U.S. Geological Survey, StreamStats for Indiana streams, accessed November 2012 at $h t t p: / / s t r e a m s t a t s . u s g s . g o v /$ indiana.html.

Whitehead, M.T., and Ostheimer, C.J., 2009, Development of a flood-warning system and flood-inundation mapping for the Blanchard River in Findlay, Ohio: U.S. Geological Survey Scientific Investigations Report 2008-5234, 9 p. 



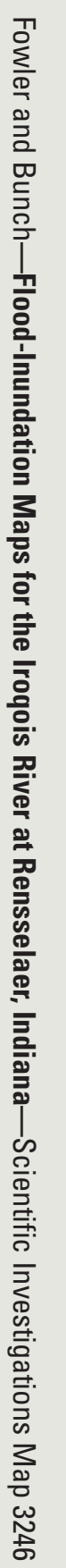

